\title{
Plasmodesmata distribution and sugar partitioning in nitrogen-fixing root nodules of Datisca glomerata
}

\author{
Maria Schubert $\cdot$ Nouria K. Koteyeva $\cdot$ Philipp W. Wabnitz $\cdot$ Patricia Santos \\ Michael Büttner $\cdot$ Norbert Sauer $\cdot$ Kirill Demchenko $\cdot$ Katharina Pawlowski
}

Received: 19 March 2010/Accepted: 21 September 2010/Published online: 12 October 2010

(C) The Author(s) 2010. This article is published with open access at Springerlink.com

\begin{abstract}
To understand carbon partitioning in roots and nodules of Datisca glomerata, activities of sucrosedegrading enzymes and sugar transporter expression patterns were analyzed in both organs, and plasmodesmal connections between nodule cortical cells were examined by transmission electron microscopy. The results indicate that in nodules, the contribution of symplastic transport processes is increased in comparison to roots, specifically in infected cells which develop many secondary plasmodesmata. Invertase activities are dramatically reduced in nodules as compared to roots, indicating that here the main
\end{abstract}

Electronic supplementary material The online version of this article (doi:10.1007/s00425-010-1285-8) contains supplementary material, which is available to authorized users.

M. Schubert · P. W. Wabnitz · K. Pawlowski ( ()

Albrecht-von-Haller-Institut für Pflanzenwissenschaften,

Biochemie der Pflanze, Georg-August-Universität Göttingen,

Justus-von-Liebig-Weg 11, 37077 Göttingen, Germany

e-mail: pawlowski@botan.su.se

N. K. Koteyeva · K. Demchenko

Laboratory of Anatomy and Morphology, Komarov Botanical

Institute, Russian Academy of Sciences, Prof. Popov st. 2,

197376 St. Petersburg, Russia

P. Santos $\cdot$ K. Pawlowski

Department of Botany, Stockholm University,

Lilla Frescativägen 5, 10691 Stockholm, Sweden

M. Büttner · N. Sauer

Abteilung für Molekulare Pflanzenphysiologie,

Friedrich-Alexander-Universität Erlangen-Nürnberg,

Staudtstr. 5, 91058 Erlangen, Germany

K. Demchenko

All-Russia Research Institute for Agricultural Microbiology,

Laboratory of Molecular and Cellular Biology, Podbelsky

Chaussee 3, Pushkin 8, 196608 St. Petersburg, Russia enzyme responsible for the cleavage of sucrose is sucrose synthase. A high-affinity, low-specificity monosaccharide transporter whose expression is induced in infected cells prior to the onset of bacterial nitrogen fixation, and which has an unusually low $\mathrm{pH}$ optimum and may be involved in turgor control or hexose retrieval during infection thread growth.

Keywords Actinorhiza - Frankia - Invertase - Rutinose · Sucrose synthase $\cdot$ Sugar transport

$\begin{array}{ll}\text { Abbreviations } \\ \text { AM } & \text { Arbuscular mycorrhiza } \\ \text { INV } & \text { Invertase } \\ \text { STP } & \begin{array}{l}\text { Sugar transport protein (monosaccharide } \\ \text { transporter) }\end{array} \\ \text { SucS } & \text { Sucrose synthase }\end{array}$

Introduction

In higher plants, carbon is transported from source organs (mature leaves) to sink organs via the phloem mostly in the form of sucrose (see e.g. Zimmermann and Ziegler 1975). Phloem unloading and post-phloem transport of carbohydrates can proceed symplastically via plasmodesmata or apoplastically via plasma membrane sugar transporters (Patrick 1997). In the latter case, sucrose is unloaded into the apoplast and either taken up by disaccharide transporters, or hydrolyzed by an apoplastic invertase and taken up by monosaccharide transporters, whereupon sucrose is partially resynthesized (Weber et al. 1997a). Uptake of sugars from the apoplast is energy-dependent and occurs 
via sugar-proton symport. Depending on the transport mechanism, sink strength can be determined by the distribution of sugar transporters or by the activities of enzymes that degrade the transport carbohydrate in the sink tissue (Patrick 1997). In case of sucrose, these enzymes are sucrose synthase and invertases. Whether the channeling of sucrose into sink metabolism occurs by sucrose synthase or invertase can affect different sugar signaling pathways and thus influence plant development (Sturm and Tang 1999).

Root nodules induced by nitrogen-fixing soil bacteria represent strong facultative sinks. For legume nodules, this sink function is underlined by the fact that nodules accumulate starch even if the bacteria they harbor cannot fix nitrogen (Malek 1988). Previous studies have indicated that during the induction of legume nodules, symplastic phloem unloading is induced (Complainville et al. 2003) and that in the infected zone of nodules, symplastic transport mechanisms are favored over apoplastic ones (Complainville et al. 2003), except between infected cells where only few plasmodesmata have been found (Abd-Alla et al. 2000). This might be due to the fact that the symbiotic bacteria has to cross the apoplast when infection threads grow from cell to cell, and thus, in case of dominant apoplastic transport mechanisms, would have uncontrolled access to plant sugars.

Sucrose synthase $(\mathrm{SucS})$ is considered to be principally responsible for the degradation of sucrose in mature nodules (Anthon and Emmerich 1990; Gordon et al. 1999). In particular, the microaerobic conditions established in the inner tissue of legume nodules to enable nitrogenase activity, favor SucS-mediated Suc cleavage (Rolletschek et al. 2002), rather than invertase-mediated hydrolysis of sucrose which requires ATP for the introduction of hexoses into glycolysis (Zeng et al. 1999).

There are two types of root nodule symbioses with nitrogen-fixing soil bacteria, rhizobial symbioses with legumes and actinorhizal symbioses between actinomycetes of the genus Frankia and a diverse group of dicotyledonous plant species, collectively called actinorhizal plants (Pawlowski and Bisseling 1996). In contrast with legume nodules, actinorhizal nodules are composed of multiple modified lateral roots with central vascular system and infected cells in the expanded cortex. Since with the exception of the suffruticose Datisca glomerata, all actinorhizal plants represent trees or woody shrubs, this symbiosis has been less extensively examined than legumes symbioses. D. glomerata nodules also accumulate large amounts of starch (Berry et al. 2004). In contrast with legumes nodules, D. glomerata nodules are well aerated and there is no evidence for microaerobic conditions in or around infected cells (Pawlowski et al. 2007), i.e. sucrose cleavage by invertase would not be disadvantaged. A further difference between Datisca sp. nodules and the generally studied types of legume nodules is the fact that in the former, the infected cells form a continuous space and are not interspersed with uninfected cells (Newcomb and Pankhurst 1982), i.e. there is no network of uninfected cells that could provide symplastic transport pathways from the vascular system to the infected cells, or vice versa, as has been proposed for legume nodules (Selker 1988; Abd-Alla et al. 2000).

The aim of this study was to understand how sucrose is transported and introduced into metabolism in nodules of D. glomerata which lack the microaerobic conditions that form a constraint on legume nodule carbon metabolism, and where no transport network of uninfected cells exists.

\section{Materials and methods}

Plant and bacterial growth conditions

Datisca glomerata (C. Presl) Baill. seeds (collected originally in Gates Canyon, Vacaville, CA, USA, and propagated further in the greenhouse described below) were germinated and grown in nitrogen-poor soil for 3 months before being transferred into aerated liquid culture in one-fourth strength nitrogen-free Hoagland's medium (Hoagland and Arnon 1938), where they were inoculated with crushed nodules of D. glomerata plants grown in nitrogen-poor soil after 2 weeks. Nodules were harvested 4-12 weeks after inoculation. Only nodules produced between April and October were used for experiments. Plants were grown in a greenhouse at $22^{\circ} \mathrm{C}$ day $/ 18^{\circ} \mathrm{C}$ night and a light intensity of 200-400 $\mu \mathrm{mol}$ photons $\mathrm{m}^{-2} \mathrm{~s}^{-1}$.

Preparation of nodules for light and transmission electron microscopy

Nodule pieces were fixed in $2.5 \%$ glutaraldehyde plus $2 \%$ paraformaldehyde in $50 \mathrm{mM}$ potassium phosphate buffer, $\mathrm{pH} 7.2$, supplemented with $2 \%$ sucrose at $4^{\circ} \mathrm{C}$ for $3 \mathrm{~h}$ after vacuum infiltration for $15 \mathrm{~min}$. Then, nodule pieces were washed 4-6 times with $50 \mathrm{mM}$ potassium phosphate buffer for 10-15 min each and post-fixed in 2\% osmium tetroxide at $4{ }^{\circ} \mathrm{C}$ over night. They were dehydrated in a graded ethanol series at $4^{\circ} \mathrm{C}$ and then gradually saturated with acetone. At $70 \%$ ethanol $/ 30 \%$ acetone nodules pieces were contrasted with $2 \%$ uranyl acetate in $70 \%$ ethanol for $2 \mathrm{~h}$ in the dark at room temperature. After further saturation with acetone, nodule pieces were embedded in an epoxy resin mixture of Epon 812 and Araldite M (Sigma-Aldrich, Taufkirchen, Germany). Ultrathin sections were prepared on a Reichert Ultracut R ultramicrotome (Reichert-Jung, Heidelberg, Germany) and were stained for transmission electron microscopy with $2 \%(\mathrm{w} / \mathrm{v})$ uranyl acetate followed 
by $2 \%(w / v)$ lead citrate. Section thickness was kept as constant as possible and varied around $70 \mathrm{~nm}$.

Determination of plasmodesmata frequency

Plasmodesmata were counted manually along the specific cell interfaces (i.e. infected/infected and infected/uninfected of mature and young infected cortical cells and uninfected/uninfected in outer and inner cortex) within the longitudinal ultrathin sections of $D$. glomerata nodules with a transmission electron microscope Hitachi H-600 (Hitachi, Tokyo, Japan) at $75 \mathrm{kV}$ at 25,000 times magnification. Only those plasmodesmata were counted that stretched further than the primary cell wall, and that were radially but not longitudinally oriented in wall sections. The interfaces measured were mature infected/uninfected cortical cells, mature infected/mature infected cortical cells, young infected/uninfected cortical cells, young infected/young infected cortical cells and uninfected/ uninfected outer and inner cortical cells.

From each specimen, semithin sections were prepared for light microscopy to measure the lengths of the respective cell-cell interfaces. Semithin sections (about $0.8-1-\mu \mathrm{m}$-thick) were made on a Reichert Ultracut $\mathrm{R}$ ultramicrotome (Reichert-Jung). Sections were stained with $1 \%(\mathrm{w} / \mathrm{v})$ toluidine blue $\mathrm{O}$ in $1 \%(\mathrm{w} / \mathrm{v}) \mathrm{Na}_{2} \mathrm{~B}_{4} \mathrm{O}_{7}$. Light microscopy was done using a BX51 microscope (Olympus Optical, Hamburg, Germany). The results were documented using a ColorView II digital camera set and SIS analySIS ${ }^{\circledR}$ software (Soft Imaging System, Münster, Germany). The cell area and lengths of the respective cellcell interfaces and plasmodesmata diameters were determined using image measurement software (UTHSCSA ImageTool) on digital light microscopy images and electron micrographs. The total number of cells examined per each cell type varied between 40 and 190 .

The PD frequency was referred as the number of plasmodesmata per $100 \mu \mathrm{m}$ of specific cell-cell contact interface length. Calculation of the number of plasmodesmata per $\mu \mathrm{m}^{2}$ cell wall surface ( $F_{\mathrm{w}}$; plasmodesmata density) was made by the formula of Gunning (see $\mathrm{Ma}$ and Peterson 2001): $F_{\mathrm{w}}=N /[L(T+1.5 R)]$ were $L$ is the length of a given cell wall $(\mu \mathrm{m}), N$ is the number of plasmodesmata along the wall, $T$ is the thickness of sections $(0.07 \mu \mathrm{m})$, and $R$ is the radius of plasmodesmata $(\mu \mathrm{m})$.

Where indicated, standard errors were determined, and analysis of variance (ANOVA) was performed with Statistica 7.0 software (StatSoft, Inc., Tulsa, OK, USA). Tukey's HSD (honest significant difference) tests were used to analyze differences between different cell types of nodule cortex on cell area and plasmodesmata diameter and frequency. All analyses were performed at $95 \%$ significance level.
Molecular biological methods

RNA was isolated using the Invisorb Spin Plant-RNA Mini Kit from Invitek (Berlin, Germany). Reverse transcriptase reactions were performed as described by the manufacturer of the enzyme (MBI Fermentas, St. Leon-Rot, Germany). cDNA was prepared from ca. $3 \mu \mathrm{g}$ of total RNA using primer MM3 (5'-CTCGAGGATCCGCGGCCGCT $\left.18^{-} 3^{\prime}\right)$, and $1 / 10$ of the cDNA was used per PCR. Routine PCR program was $30 \mathrm{~s} 94^{\circ} \mathrm{C}, 35$ cycles of $94^{\circ} \mathrm{C} 30 \mathrm{~s}$, annealing temperature $30 \mathrm{~s}, 72^{\circ} \mathrm{C} 90 \mathrm{~s}$, followed by $72^{\circ} \mathrm{C}$ for $10 \mathrm{~min}$ in the presence of $1.5 \mathrm{mM} \mathrm{MgCl}$. PCR products were cloned in pGEM-T (Promega, Madison, WI, USA; sucrose synthase) or in pGEM-T Easy (Promega; pDgSTP1) and sequenced.

Degenerate primers for sucrose synthase were $5^{\prime}$-CCI AARTTYAAYATIGTIWSICC- $3^{\prime}$ and $5^{\prime}$-GRTAIGGRTC IATRTGRAAICC- $3^{\prime}$, resulting in the amplification of $D g S u c S 1$. Part of the amplified cDNA fragment was excised from pGEM-T using an internal PstI site and the PstI site of the polylinker and subcloned in Bluescript $\mathrm{KS}^{+}$ (Stratagene, La Jolla, CA, USA). The resulting clone containing $550 \mathrm{bp}$ of the sucrose synthase cDNA (EMBL accession no. AJ459486) was termed pDgSucS1. Degenerate primers for monosaccharide transporters were $5^{\prime}$-GG WTTYGCWTTGTCWTGGGGWCC- $3^{\prime}$ and $5^{\prime}$-GGDATW CCYTTDGTYTCWGG-3' (Weig et al. 1994), resulting in the amplification of DgSTP1. The full-size cDNA of $D g S T P 1$ was obtained by RACE technology. For the 5'-RACE, the Thermoscript reverse transcriptase-PCR System Kit (Life Technologies, Carlsbad, CA, USA) was used for reverse transcription of ca. $5 \mu \mathrm{g}$ total RNA with the first gene-specific primer (5'-CGGGATTCCCTTAGTCTCGG GC- $3^{\prime}$ ) at $55^{\circ} \mathrm{C}$ for $60 \mathrm{~min}$. Nucleotides were removed by passing the reaction mixture over a spin column from the Concert ${ }^{\mathrm{TM}}$ Rapid PCR Purification System (Life Technologies). DNA was eluted from the column in $50 \mu \mathrm{l}$ terminal transferase buffer (Promega) and C-tailing was performed using $15 \mathrm{U}$ terminal transferase (Promega). 1/10 volume of the reaction mixture was used for PCR with primer 5'-GGCCACGCGTCGACTAGTACGGGIGGGIIGGGIIG-3' and the second gene-specific primer $\left(5^{\prime}\right.$-CTCCTCTGT ACTTGTAGGGA- $3^{\prime}$ ); PCR program was $94^{\circ} \mathrm{C}, 30 \mathrm{~s} ; 35$ cycles of $94^{\circ} \mathrm{C} 30 \mathrm{~s}, 58^{\circ} \mathrm{C} 30 \mathrm{~s}, 72^{\circ} \mathrm{C} 30 \mathrm{~s}$, followed by $72^{\circ} \mathrm{C}, 10 \mathrm{~min}$ in the presence of $1.5 \mathrm{mM} \mathrm{MgCl} 2$ ). $3^{\prime}$-RACE was performed like the PCRs for amplification of the original cDNA fragments, using gene-specific primer $5^{\prime}$-TC CCCCTTAGAAATACGG- $3^{\prime}$ in combination with primer MM4 (5'-CTCGAGGATCCGCGGCCGC-3'). For amplification of the full size $D g S T P 1$ cDNA, cDNA was prepared from $3 \mu \mathrm{g}$ nodule RNA using the Thermoscript RT-PCR System Kit (Life Technologies) and a $\mathrm{dT}_{20}$ primer, and the cDNA was amplified using primers 
5'-CCCTTCTCTCTTTATCTCC- ${ }^{\prime}$ and $5^{\prime}$-CAGATACAT CAAATTTGACCC-3' (PCR program as for $5^{\prime}$ RACE, but with 2 min amplification at $72^{\circ} \mathrm{C}$ ).

Gel electrophoresis of RNA was performed on $1.2 \%$ formaldehyde-agarose gels, and RNA was transferred to Amersham Hybond $\mathrm{N}$ filters (Amersham Pharmacia Biotech, Freiburg, Germany) as described by Sambrook et al. (1989). For the preparation of probes, cDNA inserts were excised from pGEM-T using SstI and SstII, and from pGEM-T Easy using EcoRI. Hybridizations with ${ }^{32} \mathrm{P}-$ labeled DNA probes were performed according to the protocol provided by the manufacturer. Filters were washed at $65^{\circ} \mathrm{C}$ in $2 \times \mathrm{SSC}, 0.1 \%$ SDS when a heterologous probe was used; for homologous probes, a second washing step in $0.1 \times \mathrm{SSC}, 0.1 \%$ SDS was applied.

DNA sequencing was performed using the ABI PRISM dRhodamine Terminator Cycle Sequencing Ready Reaction Kit (Perkin Elmer Applied Biosystems, Weiterstadt, Germany). Samples were separated using the ABI PRISM 310 Genetic Analyzer (Perkin Elmer). The full-size DgSTP 1 cDNA was sequenced by SeqLab (Göttingen, Germany). Sequence evaluation was performed with the GCG program package (Altschul et al. 1990).

\section{Invertase assays}

Plant tissue was ground to a fine powder in liquid nitrogen and re-suspended in homogenization buffer $(2 \mathrm{ml} / \mathrm{g}$ fresh weight) as described by Roitsch et al. (1995). The homogenates were centrifuged at $6,000 \mathrm{~g}$ for $10 \mathrm{~min}$ at $4^{\circ} \mathrm{C}$, the supernatant (cytosolic and vacuolar fraction) was removed and used to measure the activities of soluble invertases. The pellet (cell wall fraction) was washed three times with double-distilled $\mathrm{H}_{2} \mathrm{O}$ at $4^{\circ} \mathrm{C}$ and re-suspended in $\mathrm{ddH}_{2} \mathrm{O}$. Both fractions were dialyzed against $12.5 \mathrm{mM} \mathrm{K}$ phosphate buffer ( $\mathrm{pH} 7.4$ ) two times for $45 \mathrm{~min}$ and then overnight at $4^{\circ} \mathrm{C}$ to remove soluble sugars. Invertase activities were determined at $\mathrm{pH} 4.35$ for apoplastic invertase, $\mathrm{pH} 5.0$ for vacuolar invertase and $\mathrm{pH} 6.8$ for cytosolic invertase according to Sung et al. (1989), except that the samples were incubated for $30 \mathrm{~min}$ at $26^{\circ} \mathrm{C}$. For apoplastic invertase, the assay mixture was vortexed regularly to keep the insoluble material suspended. For determination of glucose formed from sucrose, aliquots of the incubation mixture were added immediately to the glucose assay mixture containing $100 \mathrm{mM}$ Hepes/NaOH $\mathrm{pH} 7.2,5 \mathrm{mM} \mathrm{MgCl} 2,0.5 \mathrm{mM}$ NADP, $1 \mathrm{mM}$ ATP and 1 U glucose-6 P dehydrogenase (Roche, Mannheim, Germany). The reaction was started by adding $2 \mathrm{U}$ hexokinase (Roche), and the increase in absorption at $340 \mathrm{~nm}$ was monitored in an Uvikon 922 Spectrophotometer (Kontron Embedded Computers, München, Germany). The protein content of the fractions was determined according to Bradford (1976). BSA was used for the calibration curve.

Sucrose synthase assays

Sucrose synthase activities were determined as described by Winter et al. (1998), except that only one centrifugation at $100,000 \mathrm{~g}$ for $1 \mathrm{~h}$ at $4^{\circ} \mathrm{C}$ was performed. The supernatants were desalted over Sephadex-G25 (PD 10 desalting columns, Amersham Pharmacia Biotech) and concentrated in Fugisep Maxi ${ }^{\circledR}-30$ concentrators (Intersep, Wokingham, UK) for $1 \mathrm{~h}$ at $4^{\circ} \mathrm{C}$ and then used immediately for sucrose synthase assays (Huber et al. 1996) and protein determination according to Bradford (1976).

Sucrose synthase protein immunoblot analysis

$50-100 \mathrm{mg}$ of plant material was ground to a fine powder under liquid nitrogen and used for protein isolation as described by Hohnjec et al. (1999). Protein concentrations were determined according to Bradford (1976). Aliquots $(15 \mu \mathrm{g})$ of total protein were fractionated by SDS-PAGE on $7.5 \%$ gels. Proteins were electroblotted onto Hybond ECL Nitrocellulose Membranes (Amersham Pharmacia Biotech) according to Khyse-Andersen (1984). Immunodetection was carried out using anti-sucrose synthase serum (Ross and Davies 1992) in a 1:2,000 dilution and antirabbit horseradish peroxidase conjugate (Bio-Rad, München, Germany) in a 1:3,000 dilution. Signal was detected using Hyperfilm ECL (Amersham Pharmacia Biotech). Films were developed in Kodak Develop and Fix Solutions (Kodak, Rochester, NY, USA).

In situ staining for glucose and for acidic invertase activity

Ca. $200-\mu \mathrm{m}$-thick tissue slides were hand cut. For glucose staining, the slices were denatured in $\mathrm{ddH}_{2} \mathrm{O}$ at $65^{\circ} \mathrm{C}$ for 3-10 min and then transferred into reaction medium. For invertase activity staining, slices were washed 5-6 times in $\mathrm{ddH}_{2} \mathrm{O}$ to remove endogenous glucose and then transferred into reaction medium with $100 \mathrm{mM}$ sucrose. The reaction medium consisted of $200 \mathrm{mM}$ Tris-citrate $\mathrm{pH} 6.0,20 \mu \mathrm{g} / \mathrm{ml}$ glucose oxidase, $250 \mu \mathrm{g} / \mathrm{ml}$ horseradish peroxidase (both from Sigma-Aldrich), and $300 \mu \mathrm{g} / \mathrm{ml}$ diaminobenzidine. Incubation took place at $37^{\circ} \mathrm{C}$ for 3-4 h. Afterwards tissue slices were washed in $\mathrm{ddH}_{2} \mathrm{O}$ and photographed under a microscope.

In situ hybridization

Nodules were fixed, embedded and sectioned as described by Ribeiro et al. (1995). Hybridization pretreatment, 
washing and detection of digoxigenin-labeled probes were performed essentially as described by Jackson (1991) and on the web page referenced in Long et al. (1996), except that no washes in $0.2 \times \mathrm{SSC}$ were performed before RNase treatment, and after washes in RNase buffer slides were washed first for $30 \mathrm{~min}$ in $2 \times \mathrm{SSC}$, and then for $30 \mathrm{~min}$ at $56^{\circ} \mathrm{C}$ in $0.2 \times \mathrm{SSC}$ in a shaking water bath. Hybridization conditions were as described by Ribeiro et al. (1995).

For in vitro transcription, plasmids were linearized and labeled RNA was produced using RNA polymerase in the presence of digoxigenin-labeled UTP (Roche) according to the instructions of the manufacturer. Frankia nifH antisense RNA was prepared as described by Ribeiro et al. (1995). The Frankia rRNA probe was transcribed from a 384-bp PCR product of Frankia $23 \mathrm{~S}$ rRNA in pGEMTeasy (corresponding to nucleotides 3,507-3,703 of the Frankia strain ArI3 rRNA operon; Normand et al. 1992) which was linearized with SstII and transcribed with SP6 RNA polymerase to yield antisense RNA (Pawlowski et al. 2003). pDgSTP1 was linearized with SalI and antisense RNA was produced using T7-RNA polymerase. pDgSucS1 was linearized with BamHI for antisense RNA transcription with T7-RNA polymerase, or linearized with SstI for sense RNA transcription with T3-RNA polymerase. After in vitro transcription, the template DNA was removed via treatment with RNase-free DNase, and the non-incorporated nucleotides were removed via MicroSpin ${ }^{\mathrm{TM}}$ S-300 HR columns (Amersham Pharmacia Biotech). If necessary, the labeled RNA was hydrolyzed to obtain transcripts maximally $700 \mathrm{n}$ in size.

Functional characterization of DgSTP1 by heterologous expression in yeast

For functional characterization, the DgSTP1 cDNA was cloned in sense and antisense orientation in the shuttle vector pNEV-E (Sauer and Stolz 1994) under the control of the strong promoter of the yeast plasma membrane $\mathrm{H}^{+}$ATPase (PMA1; Serrano et al. 1986). To achieve optimal expression levels, the $5^{\prime}$-untranslated region was removed from the monosaccharide transporter cDNA and replaced by the sequence $5^{\prime}$-AAGCTTGTAAAAGAA- $3^{\prime}$ from the $5^{\prime}$-untranslated region of the sucrose transporter PmSuc2 from Plantago major (Stadler et al. 1995; N. Sauer, personal communication). For this purpose, the cDNA was amplified using primers 5'-CCGGAATTCAAGCTTGTA AAAGAAATGCCGGCCGTCGGAGG- $3^{\prime}$ and $5^{\prime}$-CTAAA AATAACCCTCCCCCCAAAC- $3^{\prime}$, cloned in pGEM-T Easy, excised with EcoRI and ligated into the unique $E c o$ RI site of pNEV-E, yielding constructs pNEV-DgSTP1s and pNEV-DgSTP1as, respectively. Both constructs were then used for transformation of Saccharomyces cerevisiae strain EBY.VW4000 that carries mutations in all 18 endogenous hexose transporter genes (Wieczorke et al. 1999), yielding strains EBY.VW4000(pNEV-DgSTP1s) and EBY.VW 4000(pNEV-DgSTP1as), respectively. For uptake experiments with ${ }^{14} \mathrm{C}$-labeled sugars, strains were pre-cultured on maltose/casamino acids medium $(0.67 \%$ [w/v] yeast nitrogen base, $1 \%$ [w/v] casamino acids, $0.002 \%$ [w/v] Trp, and $2 \%$ [w/v] maltose) to an $\mathrm{OD}_{600}$ of 1 , and transport tests were performed as described by Sauer and Stadler (1993).

\section{Results}

Distribution of plasmodesmata between different types of cortical cells

Owing to the presence of an apical meristem at the tip of each nodule lobe (Fig. 1a), the infected and uninfected cortical cells of Datisca glomerata nodules are arranged in a developmental gradient. In the infection zone, infected cells are gradually filled with branching Frankia hyphae in infection thread-like structures (Fig. 1d). In the nitrogen fixation zone, a ring of radially oriented nitrogen-fixing Frankia vesicles has been formed around the central vacuole of the infected cells (Fig. 1b, c, e, f; Pawlowski et al. 2003).

To analyze symplastic transport pathways in the cortex of D. glomerata nodules, the distribution of plasmodesmata between different cell types was analyzed by transmission electron microscopy (Table 1). The results clearly show that while plasmodesmal frequency decreases from the inner to the outer side of the cortex, there are abundant plasmodesmata between uninfected and uninfected, uninfected and infected, and between infected and infected cortical cells. In short, there are no symplastically isolated cells in the cortex of D. glomerata nodules. Furthermore, a comparison of plasmodesmata numbers between infected cells of different age indicates that more than half of the plasmodesmata in the cortex of mature nitrogen-fixing infected cell are secondary in origin (Table 1). No clear cytological differences could be seen between plasmodesmata of the different cell types (Fig. 1g-m). Plasmodesmata are mainly distributed in pit fields with thicker cell walls between them (Fig. 1i-m).

Monosaccharide transporter expression in nodules versus roots

To analyze carbon partitioning and metabolism of D. glomerata, cDNAs or cDNA fragments were obtained for sucrose synthase (SucS) and a monosaccharide transporter (sugar transport protein, STP), from D. glomerata nodule RNA by reverse transcription-PCR using degenerate oligonucleotide primers. Attempts to amplify a plasma membrane sucrose transporter had proved unsuccessful; reverse transcription-PCR (RT-PCR) with degenerate 

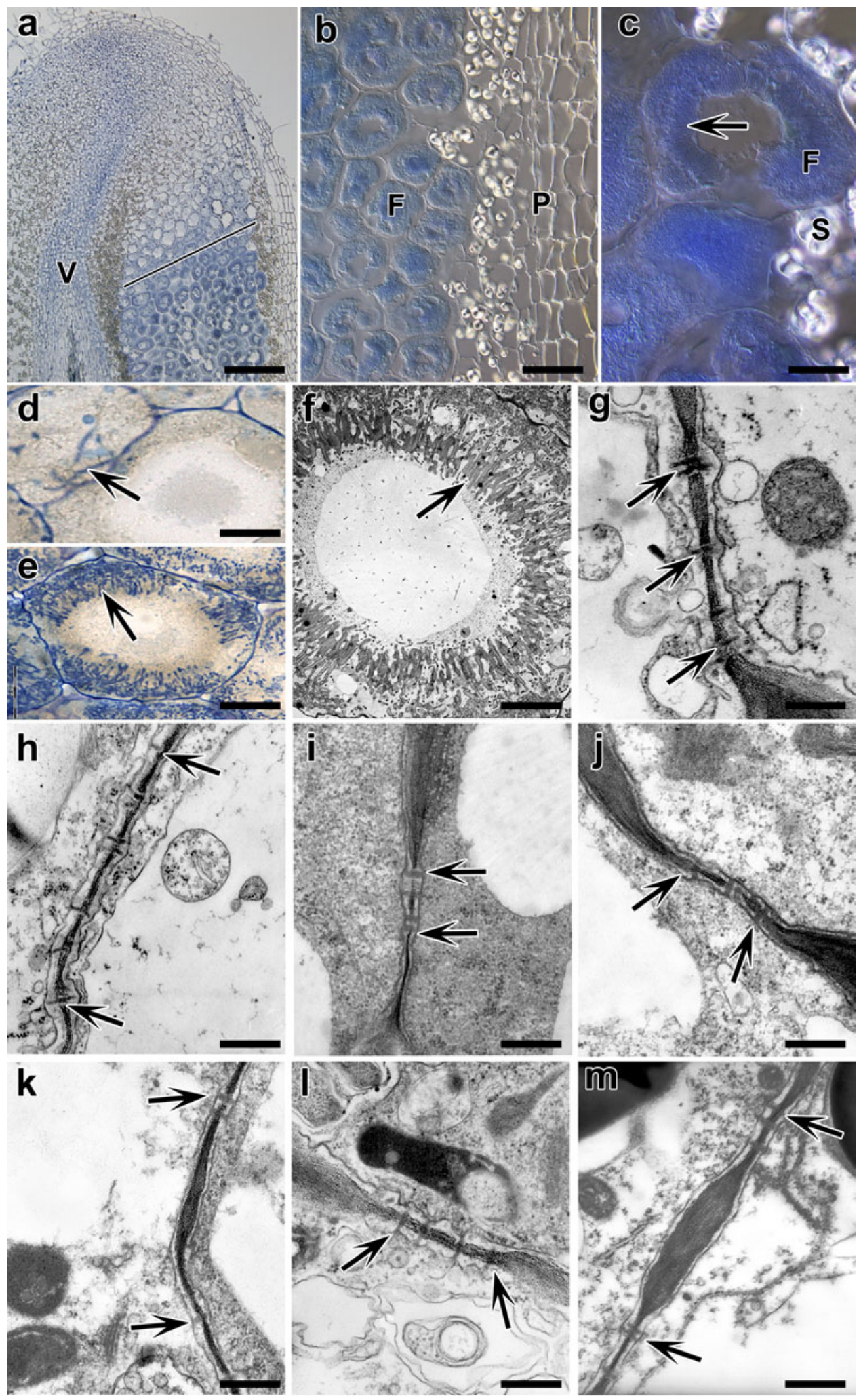

primers that had yielded diverse sucrose transporters from other plant species (Knop et al. 2001) had only led to the amplification of a putative vacuolar class III sucrose transporter (Schubert et al. 2010).
Since for the STP cDNA fragments, the same sequences were obtained in three independent RT-PCRs, it was assumed to represent the monosaccharide transporter gene dominant in nodules. The full size STP cDNA sequence 
4Fig. 1 Plasmodesmata between cortical cells in D. glomerata nodules. a Light micrograph of semithin section stained with toluidine blue: overview of longitudinally cut nodule lobe with central vascular tissue $(V)$. A line separates the infection zone (top) and the nitrogen fixation zone (bottom) of infected cells. b, c Details photographed with differential interference contrast (DIC), displaying cortical cells that either contain Frankia hyphae in infection thread-like structures and are staining in blue $(F)$, or contain large starch grains $(S)$. The nodule is surrounded by a superficial periderm $(P)$. In mature infected cells the ring of radial finger-shaped vesicles (arrow) around the central vacuole can be distinguished in c. Details of infected cells: a young infected cell which is in the process of being filled with branching hyphae in infection thread-like structures (arrow) from the periphery inward (d) and an older infected cell where Frankia has started to differentiate finger-shaped nitrogen-fixing vesicles (arrow) in radial orientation around the central vacuole (e). f Electron micrograph overview of a mature nitrogen-fixing infected cell (an arrow points at the finger-shaped radial vesicles). g Plasmodesmata (arrows) connect two uninfected cells of the inner cortex. h Plasmodesmal connections (arrows) between two uninfected cells of the outer cortex. i Plasmodesmata connecting two young infected cells. j Plasmodesmal connection between two mature nitrogen-fixing infected cells. k Plasmodesmata (arrows) between an inner cortical cell (right) and a mature nitrogen-fixing infected cell (left). 1 Plasmodesmal connections (arrows) between a mature nitrogenfixing infected cell (top) and an outer cortical cell (bottom). m Plasmodesmata (arrows) connecting two uninfected cells on the uninfected side of the nodule lobe (left part of the cortex in a). Size bars denote $200 \mu \mathrm{m}$ (a), $50 \mu \mathrm{m}$ (b), $20 \mu \mathrm{m}$ (c), $30 \mu \mathrm{m}$ (d, e), $10 \mu \mathrm{m}$ (f), and $0.2 \mu \mathrm{m}(\mathbf{g}-\mathbf{m})$

(DgSTP1) was obtained using RACE techniques (EMBL accession no. AJ459485). It comprises 1,790 nucleotides, 1,569 of which represent an ORF encoding a protein of 523 amino acids with an estimated molecular mass of $57.64 \mathrm{kDa}$. The $5^{\prime}$-untranslated region consists of 88 and the $3^{\prime}$-untranslated region of 133 nucleotides. Like the other members of the monosaccharide transporter protein family, the protein encoded by $D g S T P 1$ is predicted to represent an integral membrane protein with 12 transmembrane domains. Among the 14 monosaccharide transporters from Arabidopsis (Büttner and Sauer 2000; http://www.biologie.uni-erlangen.de/mpp/TPer/index_TP. shtml), DgSTP1 has the highest homology with AtSTP1 which is present in guard cells (Supplemental Fig. S1a; Stadler et al. 2003).

$D g S T P 1$ expression levels in roots, nodules and leaves of $D$. glomerata were examined by RNA gel blot hybridization, and $D g S T P 1$ was found to be induced in nodules as compared to roots, while its expression levels in leaves were very low (Fig. 2).

Activities of sucrose degrading enzymes in roots versus nodules from $D$. glomerata

Sucrose can be cleaved by cytosolic sucrose synthase or by cytosolic, apoplastic or vacuolar invertase. Gene expression levels do not always reflect the levels of activity of the enzymes encoded, particularly in the case of sucrosedegrading enzymes that are subject to posttranslational modification and/or the interaction with inhibitors (Krausgrill et al. 1996; Chung et al. 1999). Therefore, activities of sucrose synthase (SucS), as well as of apoplastic invertase (insoluble acid invertase), cytosolic invertase (soluble neutral invertase) and vacuolar invertase (soluble acid invertase) were determined in roots and nodules.

RNA gel blot hybridization had shown that sucrose synthase gene expression was somewhat induced in nodules as compared to roots (Fig. 2). Western blot analysis with an antibody raised against sucrose synthase from Vicia faba (Ross and Davies 1992) confirmed that sucrose synthase protein levels were higher in nodules than in roots

Table 1 Plasmodesmal frequency between different types of nodule cortical cells

\begin{tabular}{|c|c|c|c|c|c|c|}
\hline Cell type & $\begin{array}{l}\text { Cell section area } \\
{\left[\mathrm{m}^{2}\right]}\end{array}$ & $\begin{array}{l}\text { PD per cell } \\
\text { section } \\
\text { perimeter }\end{array}$ & $\begin{array}{l}\text { PD per } 100 \mu \mathrm{m} \\
\text { of cell wall }\end{array}$ & $\begin{array}{l}\text { PD per } \mu \mathrm{m}^{2} \\
\text { of cell wall }\end{array}$ & $\begin{array}{l}\text { Number of } \\
\text { cells } \\
\text { analyzed }\end{array}$ & PD diameter $[\mu \mathrm{m}]$ \\
\hline Mature infected cortical cells & $3,055.4 \pm 88.4 \mathrm{D}$ & $23.0 \pm 1.0 \mathrm{C}$ & $\begin{array}{c}14.2 \pm 0.6^{\mathrm{a} B} \\
7.25 \pm 0.97^{\mathrm{bo}} \mathrm{A} \\
17.58 \pm 2.01^{\mathrm{bi}} \mathrm{BC}\end{array}$ & $\begin{array}{l}1.49 \pm 0.06^{\mathrm{a}} \mathrm{B} \\
0.77 \pm 0.10^{\mathrm{bo}} \mathrm{A} \\
1.86 \pm 0.21^{\mathrm{bi}} \mathrm{BC}\end{array}$ & $\begin{array}{l}56 \\
60 \\
86\end{array}$ & $\begin{array}{l}0.0341 \pm 0.0009^{\mathrm{a}} \mathrm{A} \\
0.0324 \pm 0.0018^{\mathrm{bo}} \mathrm{A} \\
0.0314 \pm 0.0011^{\mathrm{bi}} \mathrm{A}\end{array}$ \\
\hline Young infected cortical cells & $1,470.2 \pm 54.1 \mathrm{C}$ & $13.3 \pm 0.8 \mathrm{~B}$ & $10.5 \pm 0.5^{\mathrm{a}} \mathrm{A}$ & $1.10 \pm 0.05^{\mathrm{a}} \mathrm{A}$ & 86 & $0.0336 \pm 0.0016^{\mathrm{a}} \mathrm{A}$ \\
\hline $\begin{array}{l}\text { Outer cortex uninfected/ } \\
\text { uninfected }\end{array}$ & $796.6 \pm 48.4 \mathrm{~A}$ & $6.0 \pm 0.7 \mathrm{~A}$ & $6.4 \pm 0.7 \mathrm{~A}$ & $0.67 \pm 0.07 \mathrm{~A}$ & 40 & $0.0338 \pm 0.001 \mathrm{~A}$ \\
\hline $\begin{array}{l}\text { Inner cortex uninfected/ } \\
\text { uninfected }\end{array}$ & $1,236.1 \pm 57.5 \mathrm{~B}$ & $19.9 \pm 1.2 \mathrm{C}$ & $24.4 \pm 1.8 \mathrm{D}$ & $2.56 \pm 0.19 \mathrm{D}$ & 40 & $0.0338 \pm 0.001 \mathrm{~A}$ \\
\hline Opposite cortex & $606.0 \pm 21.6 \mathrm{~A}$ & $8.6 \pm 0.5 \mathrm{~A}$ & $20.8 \pm 1.8 \mathrm{CD}$ & $2.26 \pm 0.20 \mathrm{CD}$ & 44 & $0.0354 \pm 0.002 \mathrm{~A}$ \\
\hline
\end{tabular}

Means are from 40 to 86 measurements \pm standard errors. Analysis was made by one-way ANOVA with Tukey's HSD (honest significant difference) test. Means followed by a different capital letter within a column indicate significant difference between different types of nodule cortical cells $(P \leq 0.05)$

$P D$ plasmodesmata, $o$ outer cortex, $i$ inner cortex, opposite cortex, cortex on the uninfected side of the acentric stele

${ }^{a}$ Infected cell/infected cell

${ }^{b}$ Infected cell/uninfected cell 


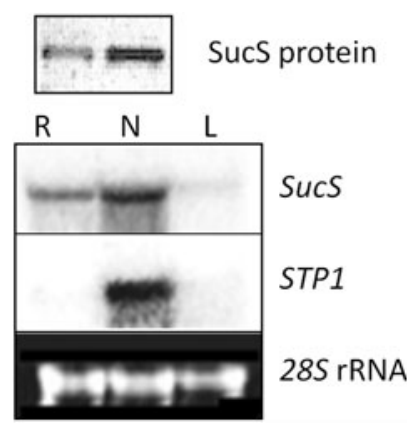

Fig. 2 SucS protein amounts and gene expression in different organs of D. glomerata. Immunodetection of SucS in total protein extracts of roots and nodules, separated by polyacrylamide gel electrophoresis, is shown. $15 \mu \mathrm{g}$ of total protein were applied per slot. For gene expression analysis, ca. $10 \mu \mathrm{g}$ total RNA from roots $(R)$, nodules $(N)$ and leaves $(L)$, respectively, were separated on a $1.2 \%$ formaldehyde agarose gel and transferred to Amersham Hybond N. The blot was hybridized successively with probes for the monosaccharide transporter (MT) and for sucrose synthase (SucS). For calibration of RNA amounts per slot, the 28S rRNA band of the gel was photographed
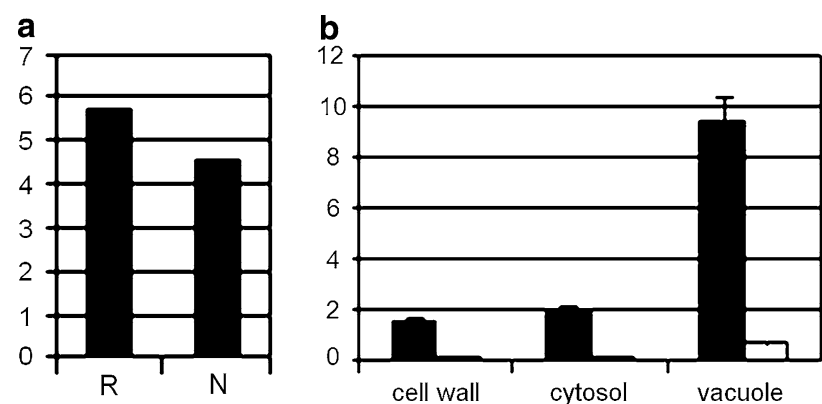

Fig. 3 Activities of sucrose-degrading enzymes in roots and nodules. a SucS activities in roots $(R)$ and nodules $(\mathrm{N})$. b Invertase activities (cell wall, cytosolic, vacuolar) in roots (black columns) and nodules (white columns). The $y$ axis values denote nanomolar sucrose hydrolyzed per minute per milligram of protein. At least five independent experiments were performed for each enzyme. The results of one representative experiment are shown in each panel

(Fig. 3a). However, sucrose synthase enzyme activities were similar in roots and nodules (Fig. 3a).

Roots of D. glomerata showed high activities of all three types of invertase (Fig. 3b). In nodules, however, invertase activities were dramatically reduced. Cytosolic and apoplastic invertase activities were hardly detectable, and vacuolar invertase activities were reduced 13 times as compared to roots (Fig. 3b). Experiments with mixed extracts showed that this reduction in activity was not due to the presence of an inhibitor in nodule extracts (data not shown).

To localize acid invertase activity in roots and nodules (the latter still contain significant vacuolar invertase activities; Fig. 3b), a glucose oxidase reaction in the presence of horseradish peroxidase and diaminobenzidine (Kim et al. 2000) was performed on hand sections of
D. glomerata roots (Fig. 4a, b). Acid invertase activity was only detected in the vascular cylinder. This method was not applicable to the infected cells of nodules, since there, diaminobenzidine was reduced independently of the presence of glucose oxidase; however, staining in nodules was restricted to the infected cells (data not shown).

In situ localization of sucrose synthase and monosaccharide transporter expression in nodules

The cell-specific expression patterns of sucrose synthase and of the monosaccharide transporter in nodules were analyzed using in situ hybridization of nodule sections with digoxigenin-labeled antisense RNA probes. Additional hybridizations with Frankia probes were carried out on adjacent sections. A Frankia rRNA antisense probe was used in order to identify infected cells (Fig. 4c). The onset of bacterial nitrogen fixation in infected cells was visualized using an antisense RNA from one of the nitrogenase structural genes, Frankia nifH (Fig. 4d; Ribeiro et al. 1995). SucS was expressed in the apical meristem of the nodule lobes and induced in cortical cells upon infection (Fig. 4f). DgSTPI expression was confined to the infected cells, with an onset after the start of infection, but preceding bacterial nitrogen fixation (Fig. 4e). In all cases, no signal was observed in sections hybridized with sense RNA (data not shown).

Because there is hardly any apoplastic invertase activity in nodules, DgSTP1 in infected cells cannot be involved in the uptake of the products of cleavage of sucrose by apoplastic invertase. To achieve a better understanding of the function of DgSTP1 in nodule metabolism, its kinetic properties were analyzed.

\section{Characterization of DgSTP1 by expression in yeast}

Saccharomyces cerevisiae strain EBY.VW4000 (Wieczorke et al. 1999) whose endogenous monosaccharide transporter genes have been deleted was used to analyze kinetic properties and substrate specificity of DgSTP1. The $K_{\mathrm{m}}$ value of DgSTP1 for glucose was $43 \mu \mathrm{M}$ (Fig. 5a), which is in the range of $K_{\mathrm{m}}$ values of other plant sugar transporters, such as AtSTP1 in Arabidopsis ( $20 \mu \mathrm{M}$; Stolz et al. 1994), AtSTP9 ( $83 \mu \mathrm{M}$; Schneidereit et al. 2003), VfSTP1 in Vicia faba (30 $\mu \mathrm{M}$; Weber et al. 1997b) or RcHEX3 in Ricinus communis $\left(80 \mu \mathrm{M}\right.$; Weig et al. 1994). The $V_{\max }$ of DgSTP1 was $2 \mathrm{nmol} \mu \mathrm{l}^{-1}$ p.c. $\mathrm{h}^{-1}$ (p.c., packed cells). Monosaccharide uptake studies with EBY.VW4000 (pDgSTP1sense) and EBY.VW4000 (pDgSTP1antisense) showed that DgSTP1 accepts several monosaccharides as substrates, but glucose at the highest affinity by far (D-glucose $\gg$ D-galactose $\geq$ D-xylose $>$ D-mannose; see Fig. 5b). Under the same conditions no significant uptake of D-ribose, D-fructose and of the non-metabolizable glucose analog 3-O-methylglucose 

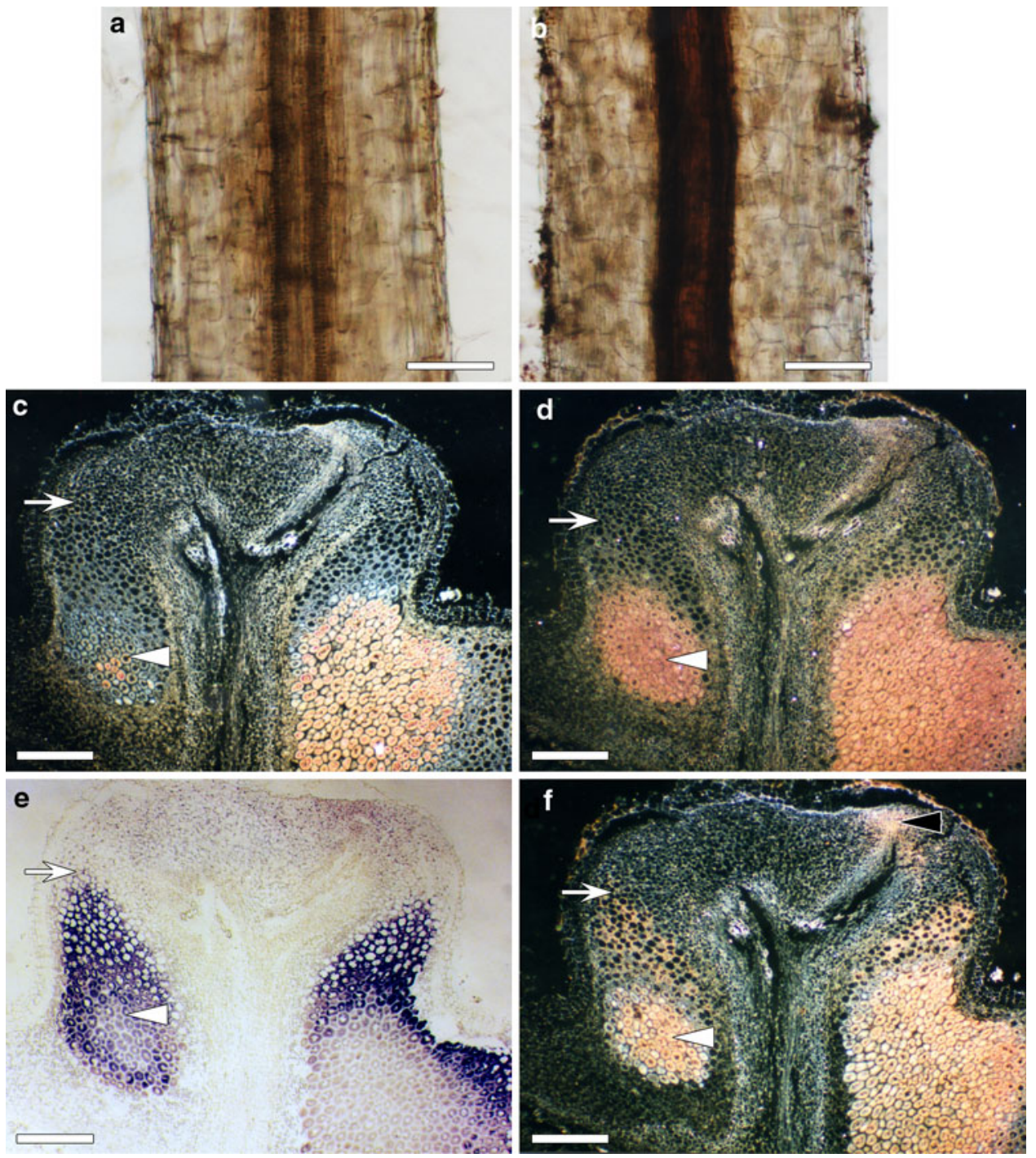

Fig. 4 In situ localization of enzyme activity and mRNAs. a, b In situ localization of acid invertase activity in roots of $D$. glomerata. Hand sections of roots were either denatured (glucose staining control a) or directly transferred into reaction medium with sucrose, glucose oxidase, horseradish peroxidase and diaminobenzidine (acidic invertase activity staining b). Dark brown color develops in the presence of glucose, i.e., acid invertase activity. In D. glomerata roots, invertase activity is confined to the stele. $\mathbf{c - f}$ In situ localization of transcripts in root nodules. Hybridizations with digoxigenin-labeled RNA are shown and the reaction product of the phosphatase-labeled antibody is visible in purple/brownish color in the bright field micrograph (e) and in orange/brownish color in dark field micrographs $(\mathbf{c}, \mathbf{d}, \mathbf{f})$.

Adjacent sections of a branching lobe of a D. glomerata nodule were hybridized with a Frankia nifH antisense probe (c), a D. glomerata STP1 antisense probe (d), a Frankia 16S rRNA antisense probe (e), and a D. glomerata SucS antisense probe (f). Thin white arrows point at the beginning of infection of cortical cells at the left lobe (based on the detection of Frankia by the 16S rRNA antisense probe in e), white arrow heads point at the first nitrogen-fixing infected cells (based on the detection of Frankia nifH expression in c). A black arrowhead points at the meristem of the right lobe in $\mathbf{f}$. No signal was found in hybridizations with sense RNA (data not shown). Size bars denote $500 \mu \mathrm{m}$

(3-OMG) could be detected. Uptake of L-rhamnose, a product of rutinose/methylrutinose degradation, was tested in a separate series of experiments; even with 1,000-fold excess, non-labeled L-rhamnose only inhibited uptake of ${ }^{14} \mathrm{C}$-Dglucose by $10 \%$, while a 1,000 -fold excess of non-labeled D-fructose which was not taken up to a significant extent (Fig. 5b) showed about 50\% inhibition (data not shown). Hence, L-rhamnose is no subtract of DgSTP1. In summary, with regard to glucose and galactose, the substrate specificity

of DgSTP1 is similar to that of the monosaccharide transporter STP9 from Arabidopsis (Schneidereit et al. 2003), but AtSTP9 has a much lower affinity to xylose and mannose than DgSTP1.

The energy dependence of monosaccharide transport by DgSTP1 was analyzed using D-glucose. No glucose transport was demonstrated in yeast cells expressing DgSTP1 in antisense orientation (data not shown). The results show that DgSTP1 catalyzes the uptake of glucose in an energy- 

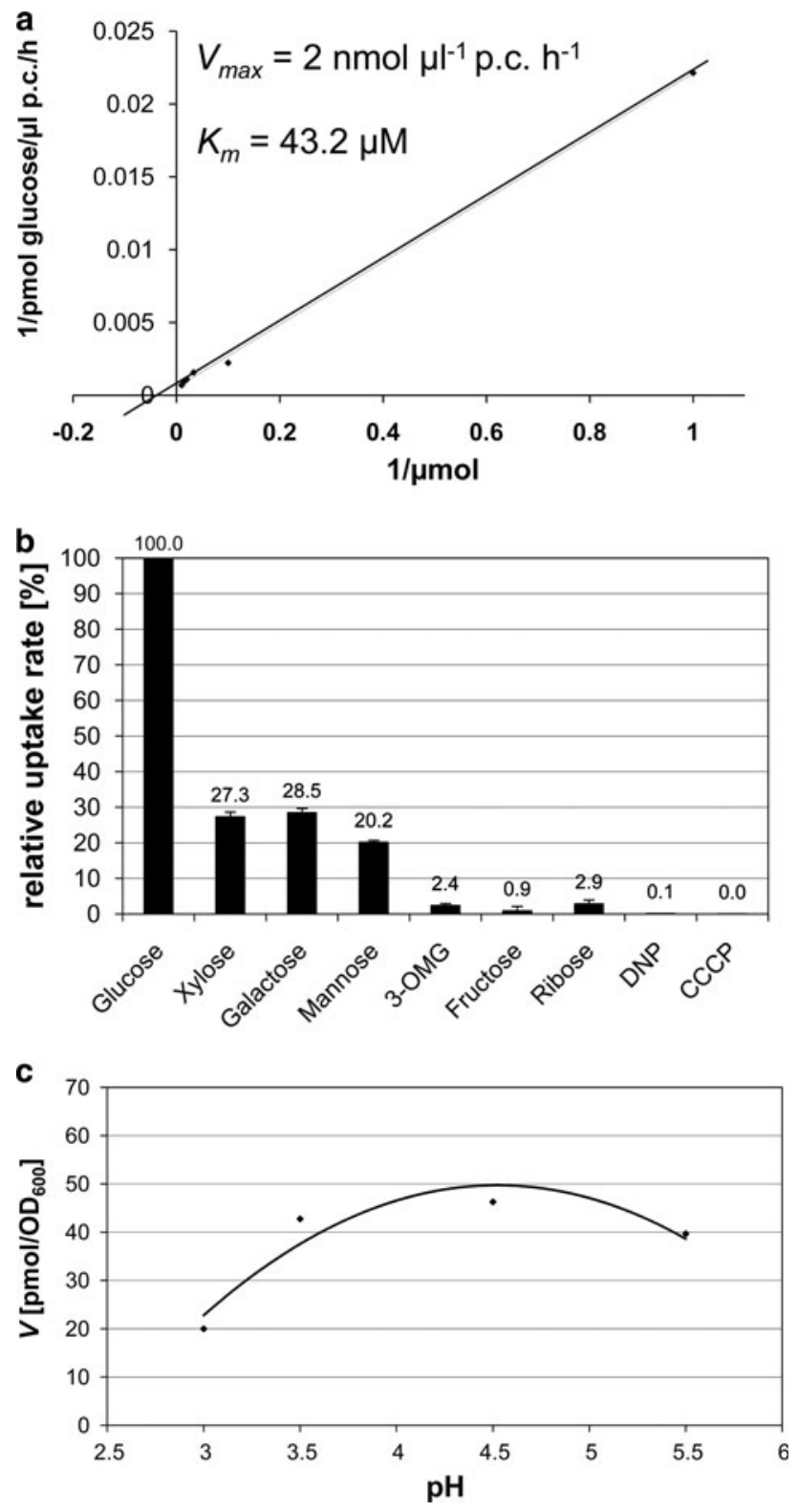

Fig. 5 Kinetic properties of the hexose transporter from D. glomerata nodules, DgSTP1. a Determination of the $K_{\mathrm{m}}$ value for D-glucose uptake of the DgSTP1-expressing yeast strain EBY.VW4000 (Wieczorke et al. 1999). The Lineweaver-Burk plot of a typical $K_{\mathrm{m}}$ determination is presented. All values were determined in $\mathrm{Na}-$ phosphate buffer ( $\mathrm{pH}$ 5.5). $p c$ Packed cells. b Substrate specificity of DgSTP1 and sensitivity to inhibitors. Relative transport rates of radiolabeled D-glucose or other potential substrates were determined at an initial outside concentration of $0.1 \mathrm{mM}$. For sensitivity to inhibitors, transport of $0.1 \mathrm{mM}{ }^{14} \mathrm{C}$-glucose was determined in the presence of the uncoupler dinitrophenol or in the presence of the SHgroup inhibitor $p$-(chloromercuri)benzene sulfonic acid. Both inhibitors were added to a final concentration of $50 \mu \mathrm{M}$. All data represent average values of two independent transport tests. $\mathbf{c}$ Determination of the $\mathrm{pH}$ optimum for glucose uptake of the $D g S T P 1$-expressing yeast strain EBY.VW4000. All values were determined at an initial outside concentration of $0.1 \mathrm{mM}{ }^{14} \mathrm{C}$-glucose dependent manner: (1) uptake rates for glucose increased in the presence of added energy source, namely $1 \%$ ethanol, while (2) uncouplers of transmembrane proton gradients, namely $50 \mu \mathrm{M}$ 2,4-dinitro phenol (DNP) or $50 \mu \mathrm{M}$ carbonyl cyanide-m-chlorophenylhydrazone (CCCP), completely abolished glucose uptake by DgSTP1 (Fig. 5b).

These results show that like all other plant monosaccharide transporters examined thus far, DgSTP1 is a highaffinity, energy-dependent transporter, probably a proton symporter, with broad substrate specificity. A comparison of the rates of D-glucose uptake by DgSTP1 in buffer systems with different $\mathrm{pH}$ values showed that the $\mathrm{pH}$ optimum of DgSTP1 was about 4.5 (Fig. 5c), whereas the $\mathrm{pH}$ optima of most other plant monosaccharide transporters examined are about 5.5 (M. Büttner, personal communication).

\section{Discussion}

Sugar metabolism in roots and nodules of Datisca glomerata

In plants, the breakdown of sucrose in sink organs is strictly controlled; amounts and activities of sucrose cleaving enzymes, sucrose synthase as well as invertases, are controlled at the transcriptional as well as posttranscriptional level (Sturm and Tang 1999). Plants that use carbon transport forms other than sucrose, i.e., raffinose family oligosaccharides (RFOs), in sink organs either use them for transient storage in the vacuoles or directly introduce them into degradative metabolism (Keller and Pharr 1996).

The phloem carbohydrate transport form of D. glomerata is sucrose (Schubert et al. 2010). D. glomerata has an unusual carbon metabolism that includes two novel free disaccharides, rutinose ( $\alpha$-L-rhamnopyranosid- $(1 \rightarrow 6)$ glucose) and its methylated non-reducing form, methylrutinose $\quad(\alpha$-L-rhamnopyranosid- $(1 \rightarrow 6)-(1-O-\beta$-D-methyl glucose) which accumulate in roots and nodules (Schubert et al. 2010). No hydrolytic rutinose-degrading enzyme activity could be detected in extracts from $D$. glomerata, suggesting that in contrast with fungi, here no hydrolytic $\alpha$-rhamnosidase activity is present, but the reaction mechanism is more complex (Schubert et al. 2010). The fact that rutinose levels in nodules were always higher than sucrose levels indicates that rutinose/methylrutinose are built up as intermediate storage forms while sucrose is used for metabolism.

Sucrose can be cleaved either by sucrose synthase (SucS) or invertase. While invertase activities were found to be 
dramatically reduced in nodules as compared to roots (Fig. 3b), SucS activity levels were similar in roots and nodules, despite the fact that based on mRNA and protein amounts, SucS was induced in nodules as compared to roots (Figs. 3, 4a). These results seem to indicate that less, or at least not more, sucrose is cleaved in roots than in nodules, which is unconvincing since the sink strength of nodules should be higher than that of roots (Chechetka et al. 1998).

Monosaccharides from sucrose degradation can go into starch biosynthesis (uninfected cells), rutinose/methylrutinose biosynthesis, be broken down for energy and carbon skeletons, or be used for cell wall biosynthesis. Accordingly, SucS can be localized in the cytosol or associated with the plasma membrane; in the latter case, it provides UDP glucose for cellulose and callose biosynthesis (Haigler et al. 2001). The membrane-bound enzyme activity which is involved in providing UDP glucose for the synthesis of cell wall material would not have been detected in the assays performed in this study where only the soluble protein fraction was examined. Because the infection of nodule cells requires the synthesis of large amounts of a cell wall-like matrix which embeds the bacterial microsymbionts, higher activities of membrane-bound SucS are expected in nodules than in roots. This would agree with the apparent induction of SucS on the mRNA and protein level which is not reflected on the level of cytosolic SucS activity. The additional SucS protein would be associated with the plasma membrane.

\section{Function of DgSTP1 in nodule metabolism}

The low expression levels of DgSTP1 in leaves indicate that it does not fulfil the function of its closest homolog among the monosaccharide transporters of Arabidopsis in guard cells. DgSTP1 is unusual among plant hexose transporter in its low $\mathrm{pH}$ optimum. This may be connected with its localization in infected cells of nodules. For legume nodules, it has been shown that the $\mathrm{pH}$ of the peribacteroid space is lower than that of the apoplast (Mellor 1989), and also in intracellular symbioses with fungi, arbuscular mycorrhiza, the periarbuscular space is more acidic than the apoplast (Guttenberger 2000). Hence, it is likely that DgSTP1 is localized in the invaginated part of the plasma membrane that is surrounding the intracellular microsymbiont, and thus adapted to higher acidity.

The data presented in this manuscript raise the question about the function of a monosaccharide transporter in nodules, where there is practically no cell wall invertase activity that would lead to the formation of monosaccharides in the apoplast by cleavage of apoplastical sucrose. The fact that DgSTPl transcription is induced specifically in infected cells allows several hypotheses regarding its function.
(1) DgSTP1 might work as an exporter and deliver glucose to the symbiotic bacteria. In the free-living state, most Frankia strains examined can grow on monosaccharides as sole carbon source, although they tend to prefer carboxylic acids (summarized by Benson and Silvester 1993). For Alnus glutinosa, a nodule-specific dicarboxylate exporter has been identified that is present in the perisymbiont membranes (Jeong et al. 2004), indicating that here, symbiotic Frankia is supplied with dicarboxylates like rhizobia in legume nodules (Streeter 1995). Since the microsymbionts of Datisca sp. cannot be cultured, their carbon source preferences cannot be determined; at any rate, they belong to a different phylogenetic group than the microsymbionts of A. glutinosa (Clawson et al. 2004). Plant monosaccharide transporters catalyze proton symport and hence, are generally considered as importers. However, the only member of this protein family examined for import and export of monosaccharides in synthetic vesicles was shown to catalyze transport in both directions (Caspari et al. 1996). Efficient uptake of monosaccharides by symbiotic Frankia might drive the monosaccharide transport by DgSTP1 in the export direction. Monosaccharide export coupled with proton export would lead to an acidification of the perisymbiont space which could be counteracted by the diffusion of ammonia, the product of nitrogen fixation, from the symbiotic bacteria, since in an acidic environment, ammonia would immediately be protonized to yield ammonium which could in turn be taken up via transporters in the plant-derived perisymbiont membrane. A similar mechanism of acidification of the peribacteroid space that requires the bacteria to exude ammonia has been proposed for legume nodules, only that here, the acidification was ascribed to the export of malate by the plant cells into the peribacteroid space (Kannenberg and Brewin 1989).

(2) The second option would be that DgSTP1, like it has been suggested for its closest homolog in Arabidopsis, AtSTP1 (Sherson et al. 2003), is involved in the salvage of monosaccharides lost during cell wall biosynthesis. As mentioned above, the infection of cortical cells requires very high activities of biosynthesis of a cell wall-like matrix. The substrate specificity of DgSTP1, while different from that of AtSTP1 (Boorer et al. 1994), strongly resembles the neutral monosaccharide composition of primary cell walls from Arabidopsis (Reiter et al. 1997). However, in the only actinorhizal plant, where this matrix was examined, Ceanothus sp., it was found to be rich in pectin, i.e., quite different in composition from the primary cell wall (Liu and Berry 1991). Furthermore, with regard to this function it would be surprising that $D g S T P 1$ expression is maintained throughout the nitrogen fixation zone although there the growth of infection thread-like structures, with the concomitant synthesis and breakdown of the cell wall-like matrix that embeds symbiotic Frankia should have ceased. 
(3) DgSTP1 might be involved in turgor control during the stable intracellular accommodation of the microsymbiont. Infection thread growth, i.e., invagination of the plasma membrane of the plant cell and tip growth (Berg et al. 1999), would require continuous local turgor control which might be achieved by the export and re-uptake of hexoses into the perisymbiont space. DgSTP1 could be responsible for the export of glucose derived from sucrose breakdown, or its re-uptake, or both. This function would also be consistent with the substrate specificity. On first view, the maintenance of $D g S T P 1$ expression throughout the nitrogen fixation zone would not seem to fit with this function, unless turgor control has to be maintained throughout the life time of infection threads. This, however, would be indeed likely to be the case since in actinorhizal plants since their infection threads, in contrast with those of legumes, do not contain an equivalent of the gradually hardening infection thread matrix that surrounds rhizobia (Brewin 2004), but directly enclose Frankia hyphae (Berg et al. 1999).

A direct comparison with the putative functions of AtSTP1 orthologues from other root nodule-forming plantsMtSTP1 from Medicago truncatula (Harrison et al. 1996; Supplemental Fig. S1b), VfSTP1 from Vicia faba (Weber et al. 1997b) and GmSTP1 from soybean (termed MSP2 in Dimou et al. 2005)—is difficult because the expression of none of the corresponding genes has been analyzed in root nodules. MtSTPl was, however, shown to be expressed specifically in arbuscule-containing root cortical cells in arbuscular mycorrhizal associations, which would support a function in turgor control during continuous invagination of the plasma membrane to internally accommodate a microbial symbiont (Harrison 1996). Also the fact that its expression in roots is induced by salt stress (Mtr.21035.1.S1_at in the M. truncatula Gene Expression Atlas http://mtgea.noble.org/v2/) could be viewed in connection with a function in turgor control. On the other hand, other members of this subgroup of hexose transportersAtSTP1 and VfSTP1-have been suggested to be involved in hexose retrieval (Weber et al. 1997b; Sherson et al. 2003). MtSTP1 is also expressed in the elongation zone of the root tip (Harrison 1996) where intense extension growth and cell wall biosynthesis would support both a function in hexose retrieval or in turgor control, respectively. In summary, based on the expression patterns of STP1 genes in different plant species, it is not possible to draw a firm conclusion regarding the function of the corresponding proteins.

Apoplastic versus symplastic sugar transport in roots and nodules of D. glomerata

In legume nodules, SucS plays the major role in introducing sucrose into metabolism. Despite the fact that $D$. glomerata nodules are well aerated, the situation here seems similar, since the activity of all three types of invertases is significantly reduced in nodules compared to roots. In situ staining for invertase activity showed that acid invertases-i.e., apoplastic and vacuolar invertases-are active in the root stele, but not in the root cortex. Hence, apoplastic sugar transport involving the hydrolysis of sucrose in the apoplast, followed by the uptake of hexoses by the adjacent cells, takes place in this tissue, while sugar transport in the root cortex either involves disaccharide transporters or occurs symplastically. The dramatic reduction in apoplastic invertase activity in nodules as compared to roots indicates that apoplastic sugar transport involving apoplastic sucrose hydrolysis does not play a significant role in nodules, either in the vascular system or in the cortex.

Regarding symplastic transport, cytological analysis of D. glomerata nodules in this study revealed that while overall plasmodesmata density decreases from the inner to the outer cortex, the whole nodule cortex represents a symplastic continuum. Mature nitrogen-fixing infected cells are connected by more plasmodesmata than young infected cells that are still in the process of being filled with Frankia hyphae, indicating that secondary plasmodesmata are formed between infected cells during the infection process (Table 1). Hence, symplastic transport potential is increased during the differentiation of infected cells.

A shift from apoplastic to symplastic transport was also found during tuberization in potato (Viola et al. 2001). The corresponding increase in cytosolic sucrose levels is considered to be instrumental in initiating and maintaining starch biosynthesis via transcriptional and posttranslational up-regulation of SucS and ADP glucose phosphorylase (Geigenberger 2003). In addition, D. glomerata nodules contain large amounts of starch in their uninfected cortical cells; however, here transcriptional SucS up-regulation seems to be confined to the infected nodule meristem and the infected side of the nodule lobe (Fig. 4f). Of course, an increase in cytosolic rutinose levels due to increased symplastic transport might also have a regulatory effect.

\section{Concluding remarks}

The analysis of plasmodesmata distribution in the cortex of D. glomerata nodules showed that symplastic connections increase in the course of nodule development, enhancing the capacity for symplastic transport processes. The downregulation of apoplastic invertase in nodules when compared with roots indicates that apoplastic sugar transport involving the hydrolysis of sucrose does not play a significant role in nodules. Based on the evidence available, a function in turgor control or hexose retrieval is proposed for the monosaccharide transporter that is expressed in nodules at rather high levels, DgSTP1. 
Acknowledgments We want to thank T. Roitsch (University of Graz, Austria) for help with invertase assays, H. Winter (University of Osnabrück, Germany) for help with sucrose synthase assays and Olga V. Voitsekhovskaja (Komarov Botanical Institute, Russian Academy of Sciences, St. Petersburg, Russia) and Dieter Heineke (University of Göttingen, Germany) for helpful discussions. The D. glomerata sucrose synthase cDNA fragment was obtained in a collaboration with A.M. Berry (UC Davis, CA, USA) in course of a Katherine Esau Fellowship awarded to K.P. K.D. acknowledges support by the Russian Fond for Basic Research (Grant no. 08-04-01710-a) and by the Russian Ministry of Education and Science (P289, P623, 02.740.11.0276). This work was supported by a Grant from the German Research Council (DFG) to K.P.

Open Access This article is distributed under the terms of the Creative Commons Attribution Noncommercial License which permits any noncommercial use, distribution, and reproduction in any medium, provided the original author(s) and source are credited.

\section{References}

Abd-Alla MH, Koyro H-W, Schubert S, Peiter E (2000) Functional structure of the indeterminate Vicia faba L. root nodules: implications for metabolite transport. J Plant Physiol 157: 335-343

Altschul SF, Gish W, Miller W, Myers EW, Lipman DJ (1990) Basic local alignment search tool. J Mol Biol 215:403-410

Anthon GE, Emmerich DW (1990) Developmental regulation of enzymes of sucrose and hexose metabolism in effective and ineffective soybean nodules. Plant Physiol 92:346-351

Benson DR, Silvester WB (1993) Biology of Frankia strains, actinomycete symbionts of actinorhizal plants. Microbiol Rev 57:293-319

Berg RH, Langenstein B, Silvester WB (1999) Development in the Datisca-Coriaria nodule type. Can J Bot 77:1334-1350

Berry AM, Murphy TM, Okubara PA, Jacobsen KR, Swensen SM, Pawlowski K (2004) Novel expression pattern of cytosolic glutamine synthetase in nitrogen-fixing root nodules of the actinorhizal host, Datisca glomerata. Plant Physiol 135:1849-1862

Boorer KJ, Loo DDF, Wright EM (1994) Steady-state and presteadystate kinetics of the $\mathrm{H}^{+}$/hexose cotransporter (STP1) from Arabidopsis thaliana expressed in Xenopus oocytes. J Biol Chem 269:20417-20424

Bradford MM (1976) A rapid and sensitive method for the determination of microgram quantities of protein utilizing the principle of protein-dye binding. Anal Biochem 72:248-254

Brewin NJ (2004) Plant cell wall remodelling in the rhizobiumlegume symbiosis. Crit Rev Plant Sci 23:293-316

Büttner M, Sauer N (2000) Monosaccharide transporters in plants: structure, function and physiology. Biochim Biophys Acta 1465: 263-274

Caspari T, Robl I, Stotz J, Tanner W (1996) Purification of the Chlorella HUP1 hexose-proton symporter to homogeneity and its reconstitution in vitro. Plant J 10:1045-1053

Chechetka SA, Piskorskaya VP, Bruskova RK, Troitskaya GN, Izmailov SF (1998) Partitioning of ${ }^{14} \mathrm{C}$-photoassimilates in soybean plants assimilating of symbiotic and nitrate nitrogen. Russ J Plant Physiol 45:203-208

Chung HJ, Sehnke PC, Ferl RJ (1999) The 14-3-3 proteins: cellular regulators of plant metabolism. Trends Plant Sci 4:367-371

Clawson ML, Bourret A, Benson DR (2004) Assessing the phylogeny of Frankia-actinorhizal plant nitrogen-fixing root nodule symbioses with Frankia 16S rRNA and glutamine synthetase gene sequences. Mol Phylogenet Evol 31:131-138

Complainville A, Brocard L, Roberts I, Dax E, Sever N, Sauer N, Kondorosi A, Wolf S, Oparka K, Crespi M (2003) Nodule initiation involves the creation of a new symplasmic field in specific root cells of Medicago species. Plant Cell 15:2778-2791

Dimou M, Flemetakis E, Delis C, Aivalakis G, Spyropoulos KG, Katinakis P (2005) Genes coding for a putative cell-wall invertase and two putative monosaccharide $/ \mathrm{H}^{+}$transporters are expressed in roots of etiolated Glycine max seedlings. Plant Sci 169:798-804

Geigenberger P (2003) Regulation of sucrose to starch conversion in growing potato tubers. J Exp Bot 54:457-465

Gordon AJ, Minchin FR, James CL, Komina O (1999) Sucrose synthase in legume nodules is essential for nitrogen fixation. Plant Physiol 120:867-877

Guttenberger M (2000) Arbuscules of vesicular-arbuscular mycorrhizal fungi inhabit an acidic compartment within plant roots. Planta 211:299-304

Haigler CH, Ivanova-Datcheva M, Hogan PS, Salnikov VV, Hwang S, Martin K, Delmer DP (2001) Carbon partitioning to cellulose synthesis. Plant Mol Biol 47:29-51

Harrison MJ (1996) A sugar transporter from Medicago truncatula: altered expression pattern in roots during vesicular-arbuscular (VA) mycorrhizal associations. Plant J 9:491-503

Hoagland DR, Arnon DT (1938) The water-culture method for growing plants without soil. California Agriculture Experimental Station Circular, p 347

Hohnjec N, Becker JD, Pühler A, Perlick AM, Küster H (1999) Genomic organization and expression properties of the MtSucS1 gene, which encodes a nodule-enhanced sucrose synthase in the model legume Medicago truncatula. Mol Gen Genet 261: $514-522$

Huber SC, Huber JL, Liao PC, Gage DA, McMichael P Jr, Courey PS, Hannah LC, Koch K (1996) Phosphorylation of serine-15 of maize leaf sucrose synthase. Plant Physiol 112:793-802

Jackson D (1991) In situ hybridization in plants. In Bowles DJ, Gurr SF, McPherson M (eds) Molecular plant pathology: a practical approach. Oxford University Press, Oxford, pp 163-174

Jeong J, Suh S, Guan C, Tsay YF, Moran N, Oh CJ, An CS, Demchenko KN, Pawlowski K, Lee Y (2004) A nodule-specific dicarboxylate transporter from alder is a member of the peptide transporter family. Plant Physiol 134:969-798

Kannenberg EL, Brewin NJ (1989) Expression of a cell-surface antigen from Rhizobium leguminosarum 3841 is regulated by oxygen and $\mathrm{pH}$. J Bacteriol 171:4543-4548

Keller F, Pharr DM (1996) Metabolism of carbohydrates in sinks and sources: galactosyl-sucrose oligosaccharides. In: Zamski E, Schaffer AA (eds) Photoassimilate distribution in plants and crops. Marcel Dekker, New York, pp 115-184

Khyse-Andersen J (1984) Electroblotting of multiple gels: a simple apparatus without buffer tank for rapid transfer of proteins from polyacrylamide to nitrocellulose. J Biochem Biophys Methods 10:203-209

Kim J-Y, Mahé A, Brangeon J, Prioul J-L (2000) A maize vacuolar invertase, IVR2, is induced by water stress, organ/tissue specificity and diurnal modulation of expression. Plant Physiol 124:71-84

Knop C, Voitsekhovskaja O, Lohaus G (2001) Sucrose transporters in two members of the Scrophulariaceae with different types of transport sugar. Planta 213:80-91

Krausgrill S, Sander A, Greiner S, Weil M, Rausch T (1996) Regulation of cell wall invertase by a proteinaceous inhibitor. J Exp Bot 47:1193-1198

Liu QQ, Berry AM (1991) Localization and characterization of pectic polysaccharides in roots and root-nodules of Ceanothus spp. 
during intercellular infection by Frankia. Protoplasma 163:93-101

Long JA, Moan EI, Medford JI, Barton MK (1996) A member of the KNOTTED class of homeodomain proteins encoded by the STM gene of Arabidopsis. Nature 379:66-69

Ma F, Peterson CA (2001) Frequencies of plasmodesmata in Allium сера L. roots: implications for solute transport pathways. J Exp Bot 52:1051-1061

Malek W (1988) Microscopic structure of ineffective alfalfa nodules formed by auxotrophic mutants of Rhizobium meliloti. J Basic Microbiol 28:651-658

Mellor RB (1989) Bacteroides in the rhizobium-legume symbiosis inhabit a plant internal lytic compartment-implications for other microbial endosymbioses. J Exp Bot 40:831-839

Newcomb W, Pankhurst CE (1982) Fine structure of actinorhizal nodules of Coriaria arborea (Coriariaceae). New Zeal J Bot 20:93-103

Normand P, Gouy M, Cournoyer B, Simonet R (1992) Nucleotide sequence of nifD from Frankia alni strain ARI3-phylogenetic inferences. Mol Biol Evol 9:495-506

Patrick JW (1997) Phloem unloading-sieve element unloading and post-sieve element transport. Annu Rev Plant Physiol Plant Mol Biol 48:191-222

Pawlowski K, Bisseling T (1996) Rhizobial and actinorhizal symbioses: what are the shared features? Plant Cell 8:18991913

Pawlowski K, Swensen S, Guan C, Hadri A-E, Berry AM, Bisseling T (2003) Distinct patterns of symbiosis-related gene expression in actinorhizal nodules from different plant families. Mol Plant Microbe Interact 16:796-807

Pawlowski K, Jacobsen KR, Alloisio N, Denison RF, Klein M, Winzer T, Sirrenberg A, Guan C, Berry AM (2007) Truncated hemoglobins in actinorhizal nodules of Datisca glomerata. Plant Biol 9:776-785

Reiter WD, Chapple C, Somerville CR (1997) Mutants of Arabidopsis thaliana with altered cell wall polysaccharide composition. Plant J 12:335-345

Ribeiro A, Akkermans ADL, van Kammen A, Bisseling T, Pawlowski K (1995) A nodule-specific gene encoding a subtilisin-like protease is expressed in early stages of actinorhizal nodule development. Plant Cell 7:785-794

Roitsch T, Bittner M, Godt DE (1995) Induction of apoplastic invertase of Chenopodium rubrum by D-glucose and a glucose analog and tissue-specific expression suggest a role in sinksource regulation. Plant Physiol 108:285-294

Rolletschek H, Borisjuk L, Koschorreck M, Wobus U, Weber H (2002) Legume embryos develop in a hypoxic environment. J Exp Bot 53:1099-1107

Ross HA, Davies HV (1992) Purification and characterization of sucrose synthase from the cotyledons of Vicia faba L. Plant Physiol 100:1008-1013

Sambrook J, Fritsch EF, Maniatis T (1989) Molecular cloning: a laboratory manual, 2nd edn. Cold Spring Harbor Laboratory, Plainview

Sauer N, Stadler R (1993) A sink-specific $\mathrm{H}^{+} /$monosaccharide cotransporter from Nicotiana tabacum-cloning and heterologous expression in bakers-yeast. Plant J 4:601-610

Sauer N, Stolz J (1994) SUC1 and SUC2-2 sucrose transporters from Arabidopsis thaliana - expression and characterization in bakers yeast and identification of the histidine-tagged protein. Plant $\mathrm{J}$ 6:67-77

Schneidereit A, Scholz-Starke J, Büttner M (2003) Functional characterization and expression analyses of the glucose-specific
AtSTP9 monosaccharide transporter in pollen of Arabidopsis. Plant Physiol 133:182-190

Schubert M, Melnikova AN, Mesecke N, Zubkova EK, Fortte R, Batashev DR, Barth I, Sauer N, Gamalei YuV, Mamushina NS, Tietze L, Voitsekhovskaja OV, Pawlowski K (2010) Two novel disaccharides, rutinose and methylrutinose, are involved in carbon metabolism in Datisca glomerata. Planta 231:507-521

Selker JML (1988) Three-dimensional organization of uninfected tissue in soybean root nodules and its reaction to cell specialization in the central region. Protoplasma 147:178-190

Serrano R, Kielland-Brandt MC, Fink GR (1986) Yeast plasma membrane ATPase is essential for growth and has homology with $\left(\mathrm{Na}^{+}+\mathrm{K}^{+}\right), \mathrm{K}^{+}$- and $\mathrm{Ca}^{2+}$-ATPases. Nature 319:689-693

Sherson SM, Alford HL, Forbes SM, Wallace G, Smith SM (2003) Roles of cell-wall invertases and monosaccharide transporters in the growth and development of Arabidopsis. J Exp Bot 54: 525-531

Stadler R, Brandner J, Schulz A, Gahrtz M, Sauer N (1995) Phloem loading by the PmSUC2 sucrose carrier from Plantago major occurs into companion cells. Plant Cell 7:1545-1554

Stadler R, Büttner M, Ache P, Hedrich R, Ivashikina N, Melzer M, Shearson SM, Smith SM, Sauer N (2003) Diurnal and lightregulated expression of AtSTP1 in guard cells of Arabidopsis. Plant Physiol 133:528-537

Stolz J, Stadler R, Operakova M, Sauer N (1994) Functional reconstitution of the solubilized Arabidopsis thaliana STP1 monosaccharide- $\mathrm{H}^{+}$symporter in lipid vesicles and purification of the histidine tagged protein from transgenic Saccharomyces cerevisiae. Plant J 6:225-233

Streeter JG (1995) Recent developments in carbon transport and metabolism in symbiotic systems. Symbiosis 19:175-196

Sturm A, Tang G-Q (1999) The sucrose-cleaving enzymes of plants are crucial for development, growth and carbon partitioning. Trends Plant Sci 4:401-407

Sung S-J, Xu D-P, Black CC (1989) Identification of actively filling sucrose sinks. Plant Physiol 89:1117-1121

Viola R, Roberts AG, Haupt S, Gazzani S, Hancock RD, Marmiroli N, Machray GC, Oparka KJ (2001) Tuberization in potato involves a switch from apoplastic to symplastic phloem unloading. Plant Cell 13:385-398

Weber H, Borisjuk L, Heim U, Sauer N, Wobus U (1997a) A role for sugar transporters during seed development: molecular characterization of a monosaccharide and a sucrose carrier in fava bean seeds. Plant Cell 9:895-908

Weber H, Borisjuk L, Wobus U (1997b) Sugar import and metabolism during seed development. Trends Plant Sci 2:169-174

Weig A, Franz J, Sauer N, Komor E (1994) Isolation of a family of cDNA clones from Ricinus communis L. with close homology to the monosaccharide carriers. J Plant Physiol 143:178-183

Wieczorke R, Krampe S, Weierstall T, Freidel K, Hollenberg CP, Boles E (1999) Concurrent knock-out of at least 20 transporter genes is required to block uptake of hexoses in Saccharomyces cerevisiae. FEBS Lett 31:123-128

Winter H, Huber JL, Huber SC (1998) Identification of sucrose synthase as an actin-binding protein. FEBS Lett 430:205-208

Zeng Y, Wu Y, Avigne WT, Koch KE (1999) Rapid repression of maize invertase by low oxygen. Invertase/sucrose synthase balance, sugar signaling potential, and seedling survival. Plant Physiol 121:599-608

Zimmermann MH, Ziegler H (1975) Transport in plants. I. Phloem transport. In: Zimmermann MH, Milburn JA (eds) Encyclopedia of plant physiology, New Series, vol 1. Springer, Berlin, pp 480-503 